\title{
EFEKTIVITAS PENCARIAN RUTE RUMAH KOS DAN KONTRAKAN BERBASIS ALGORITMA DIJKSTRA DAN ASTAR
}

\author{
Moh Nur Latuconsina ${ }^{1}$ Agung Triayudi ${ }^{2}$ Aris Gunaryati ${ }^{3}$ \\ Teknik Informatika, Fakultas Teknologi Komunikasi dan Informatika, Universitas \\ Nasional \\ Jalan Sawo Manila, Pasar Minggu, Kota Jakarta Selatan, Daerah Khusus Ibukota \\ Jakarta \\ $\underline{\text { molatuconsina@gmail.com }}^{1} \underline{\text { agungtriayudi@civitas.unas.ac.id }}^{2}$ \\ aris.gunaryati@civitas.unas.ac.id ${ }^{3}$
}

\begin{abstract}
Today we live in a digital age, where all things in our life. Technological developments make the exchange of information so fast. How to get information is also very easy. The digital era that we are experiencing today actually goes hand in hand with the growth of the human population which is also increasing so fast. Technological sophistication has not been able to provide a significant solution regarding the need for a place to live. This has made the purchase price of a house more expensive, especially in the capital city and its surroundings. The higher the purchase price of a house makes many people prefer to live in a boarding house or rented house, this is because the rental price is relatively cheap instead of buying a house. For example, in the city of Jakarta, around the campus, there are many boarding houses and rented houses due to the large number of National University students from various regions throughout Indonesia. Therefore, in this study created a THE EFFECTIVENESS OF SEARCHING FOR KOS AND RENTAL HOUSE BASED ON THE ALGORITHM OF DIJKSTRA AND ASTAR ". This website development uses PHP language with Laravel framework and uses Atom as a text editor. This website requires an internet network to display data, view directions via google maps, and to contact the owner via whatsapp. Based on the results of testing and implementation, it can be concluded that this website was successfully created. This website can make it easier for new students of the National University of Jakarta to find boarding houses or rented houses around the campus. created. This website can make it easier for new students of the National University of Jakarta to find boarding houses or rented houses around the campus.
\end{abstract}

Keywords: Dijkstra's Algorithm, Astar Algorithm, Boarding House, Website

\section{Abstrak}

Saat ini kita hidup di era digital, di mana semua hal dalam kehidupan kita. Perkembangan teknologi membuat pertukaran informasi menjadi begitu cepat. Cara mendapatkan informasi pun sangat mudah. Era digital yang kita alami saat ini ternyata berjalan beriringan dengan pertumbuhan populasi manusia yang juga meningkat begitu cepat. Kecanggihan teknologi ternyata belum bisa memberikan solusi yang signifikan mengenai kebutuhan akan tempat tinggal. Hal tersebut membuat harga beli rumah semakin mahal terutama di kawasan Ibu kota dan sekitarnya. Harga beli rumah yang semakin tinggi membuat banyak orang lebih memilih tinggal di sebuah rumah kos ataupun rumah kontrakan hal ini dikarenakan harga sewa yang terbilang murah ketimbang membeli sebuah rumah. Sebagai contoh, di Kota Jakarta tepatnya di sekitar kampus terdapat banyak rumah kos dan 
rumah kontrakan dikarenakan banyaknya mahasiswa Universitas Nasional dari berbagai daerah di seluruh Indonesia. Oleh karena itu dalam penelitian ini dibuat "EFEKTIVITAS PENCARIAN RUMAH KOS DAN KONTRAKAN BERBASIS ALGORITMA DIJKSTRA DAN ASTAR". Pembuatan website ini menggunakan bahasa PHP dengan framework Laravel dan menggunakan Atom sebagai text editor. Website ini membutuhkan jaringan internet untuk menampilkan data, melihat petunjuk arah melalui google maps, dan untuk menghubungi pemilik via whatsapp. Berdasarkan hasil uji coba dan implementasi, dapat disimpulkan bahwa website ini berhasil dibuat. Website ini dapat mempermudah mahasiswa baru Universitas Nasional Jakarta dalam mencari rumah kos atau kontrakan di sekitar kampus.

Kata Kunci: Algoritma Dijkstra, Algoritma Astar, Rumah Kos, Website

\section{PENDAHULUAN}

Saat ini kita hidup di era digital, di mana semua hal dalam kehidupan kita, baik dalam bidang pendidikan, kesehatan, hiburan, life style, dan lain-lainnya sudah terkomputerisasi atau ter-digitalisasi. Perkembangan teknologi membuat pertukaran informasi menjadi begitu cepat. Cara mendapatkan informasi pun sangat mudah. Internet membuat semua orang saling terhubung. Kehadiran media sosial membuat derasnya informasi tak bisa dibendung lagi.

Era digital yang kita alami saat ini ternyata berjalan beriringan dengan pertumbuhan populasi manusia yang juga meningkat begitu cepat. Kecanggihan teknologi ternyata belum bisa memberikan solusi yang signifikan mengenai kebutuhan akan tempat tinggal. Hal tersebut membuat harga beli rumah semakin mahal terutama di kawasan Ibu kota dan sekitarnya. Akibatnya sebagian orang lebih memilih tinggal di sebuah rumah kos ataupun kontrakan karena harga sewa yang terbilang lebih murah ketimbang membeli sebuah rumah [1]. Terlebih lagi mereka yang merantau jauh dari kampung halaman untuk bekerja ataupun melanjutkan Pendidikan. Sebagai contoh, di Kota Jakarta tepatnya di daerah sekitar kampus Universitas Nasional terdapat banyak rumah kos dan rumah kontrakan dikarenakan banyaknya mahasiswa Universitas Nasional dari berbagai daerah di seluruh Indonesia. Kendala yang dirasakan oleh mahasiswa baru yang merantau dari luar Jabodetabek adalah sulitnya mencari rumah kos atau rumah kontrakan dengan harga yang sesuai dan fasilitas yang memenuhi kebutuhan mereka. Perkembangan teknologi seharusnya bisa mengatasi masalah tersebut. Hal yang dibutuhkan hanyalah sebuah platform yang menampung berbagai informasi mengenai rumah kos dan kontrakan yang mereka cari.

Telah dilakukan penelitian yang berjudul sistem informasi geografis pariwisata berbasis web dan pencarian jalur terpendek dengan algoritma Dijkstra di Timor Leste. Untuk membantu kementerian pariwisata Timor Leste dalam mengembangkan industri pariwisata untuk memperoleh informasi yang mudah diakses dari berbagai tempat melaluir internet. Pemetaan SIG pariwisata berbasis web menggunakan Google Maps dan Algoritma Dijkstra untuk mencari jalur terpendek dari satu titik ke titik lain pada suatu graf. Algoritma Dijkstra dapat melakukan pencarian jalur terpendek dari posisi titik awal user ke tempat obyek lokasi dengan nilai keakuratan jarak rata-rata $0.03 \%$ terhadap pengukuran. Hasil 
pencarian rute terpendek berupa jarak, rute perjalanan dan waktu tempuh dengan keceptan rata-rata kendaraan yang ditentukan secara bervariasi [2].

Pada penelitian sebelumnya, Google Maps digunakan sebagai parameter keoptimalan karena Google Maps merupakan peta digital yang telah sering digunakan oleh masyarakat. Dengan adanya Kecerdasan Buatan dan Algoritma Pencarian rute terdekat pada Google Maps, kini semakin dimudahkan untuk mencari lokasi dari rute yang terdekat sehingga lebih efisien dalam hal waktu dan tenaga. Dalam implementasinya, algoritma pencarian sangat berguna dalam mencari rute terdekat. Diantaranya, Algoritma A* (A Star) dan Algoritma Dijkstra. Kedua Algoritma tersebut bekerja dengan Mekanisme yang berbeda. Perbedaan tersebut dibandingkan dengan menggunakan Pathfinding.js. Output yang dikeluarkan diambil berdasarkan lamanya waktu pemrosesan dari setiap algoritma dalam menentukan jarak terdekat. Semakin cepat waktu pemrosesan suatu Algoritma, maka akan semakin baik untuk diimplementasikan ke dalam suatu aplikasi. Setelah melakukan penelitian didapatkan hasil bahwa kinerja Algoritma A* lebih baik dari Algoritma Dijkstra dengan rata-rata waktu $0.37 \mathrm{~ms}$ dan jumlah langkah sebanyak 200, sedangkan algoritma Dijkstra mempunyai rata-rata waktu $0.41 \mathrm{~ms}$ dan jumlah langkah 497 [3].

Pada penelitian berikutnya, aplikasi pemetaan ini merupakan sebaran dari lokasi pendidik bersertifikat dengan menerapkan Algoritma Dijkstra. Sehingga dengan adanya aplikasi ini diharapkan pendataan guru profesional atau yang sudah tersertifikasi untuk jenjang Sekolah Dasar Negeri Algoritma Dijkstra Provinsi Lampung dapat terpantau dan diketahui oleh Dinas Pendidikan Kota Bandar Lampung. Berdasarkan beberapa penelitian sebelumnya, maka penulis untuk memilih algoritma Dijkstra dan Astar sebagai algoritma pemrosesan backend aplikasi [4].

Untuk itu dalam penulisan ini, penulis membuat sebuah website untuk membantu para mahasiswa baru Universitas Nasional Jakarta yang merantau dari luar daerah untuk mencari rumah kos atau kontrakan sesuai dengan harga dan fasilitas yang mereka butuhkan. Berdasarkan hal tersebut penulis mengangkat judul "EFEKTIVITAS PENCARIAN RUTE RUMAH KOS DAN KONTRAKAN BERBASIS ALGORITMA DiJKSTRA DAN ASTAR"

\section{METODOLOGI PENELITIAN}

Berikut merupakan alur proses penelitian dari aplikasi serta pengimplementasian algoritma di dalam alur proses. 


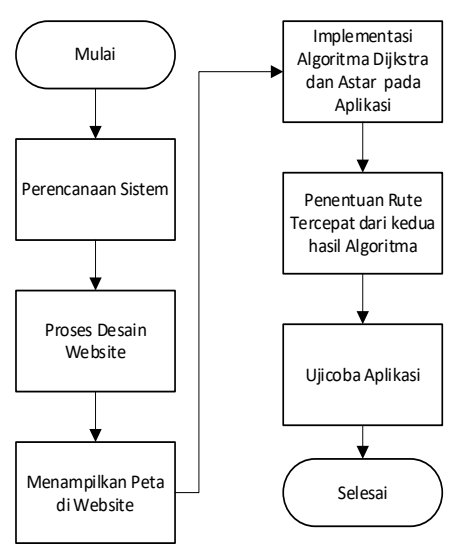

Gambar 1. Proses untuk Penelitian dan Pembangunan Sistem

Gambar 1 adalah proses untuk penelitian dan pembangunan sistem informasi kontrakan dan kosan berbasis web dan pencarian jalur terpendek dengan algoritma Dijkstra, pemetaan peta dengan Google Maps.

\subsection{Algoritma Astar ( $\left.A^{*}\right)$}

Algoritma $A^{*}$ dikembangkan oleh Hart, Nilsson, dan Raphael, algoritma ini paling popular dan telah digunakan secara luas dalam graph traversal, penemuan jalur, serta proses perencanaannya.

Prinsip dari algoritma $\mathrm{A}^{*}$ adalah melakukan traversal satu per satu pada tiap simpul untuk memperoleh lintasan terpendek [5]. Algoritma ini akan menghitung jarak salah satu lintasan, lalu menyimpannya dan kemudian menghitung jarak lintasan lainnya. Ketika seluruh lintasan telah selesai dihitung, algoritma $A^{*}$ akan memilih lintasan yang paling pendek.

Algoritma $A^{*}$ merupakan penyempurnaan dari Algoritma Dijkstra dan Membentuk Algoritma Best First Search (BFS) paling pertama.Algoritma A* akan bekerja dengan menjumlahkan $g(n)$, yaitu jumlah pergerakan dari satu node ke node lain dan $h(n)$ yaitu perkiraan biaya dari node $n$ ke tempat tujuan akhir [3]. Sehingga di dapatkan Persamaan:

$$
f(n)=g(n)+h(n)
$$

$\boldsymbol{f}(\boldsymbol{n})$ = total biaya (jarak) yang diperlukan untuk jalan dari satu node ke tujuan.

$\boldsymbol{h}(\boldsymbol{n})$ = perkiraan biaya (jarak) dari node $\mathrm{n}$ ke tujuan akhir (heuristik).

$\boldsymbol{g}(\boldsymbol{n})=$ jumlah pergerakan dari satu node ke node lain. (graph)

\subsection{Algoritma Dijkstra}

Data peta digital merupakan gambaran umum (konvensional) dari sebagian atau keseluruhan keadaan permukaan suatu wilayah. Untuk mencari lokasi kontrakan/kosan maka peta digital tersebut ditampilkan dalam web. Data jarak akan memberikan informasi yang akurat untuk mendapatkan waktu tempuh, 
sedangkan data foto-foto sekitar kontrakan/kosan akan memberikan gambaran kondisi nyata lokasi obyek tersebut [6].

Variabel data yang digunakan dalam penelitian ini adalah:

a. Peta digital daerah kontrakan/kosan yang terskala dan berkoordinat.

b. Graf pada peta (berupa jalan)

Proses Algoritma Dijkstra dalam mencari lintasan terpendek dari suatu simpul ke semua pasangan simpul algoritma Dijkstra melalui sejumlah langkah yang menggunakan prinsip greedy. Selain matriks ketetanggaan $M$, algoritma ini menggunakan tabel $S=$ [si], dengan si $=1$, jika simpul i termasuk ke dalam lintasan terpendek dan sebaliknya si $=0$, jika simpul i tidak termasuk ke dalam lintasan terpendek dan juga tabel $\mathrm{D}=[\mathrm{di}]$, dengan di = panjang lintasan dari simpul awal a ke simpul i [2].

Flowchart proses algoritma Dijkstra disajikan pada Gambar 2.

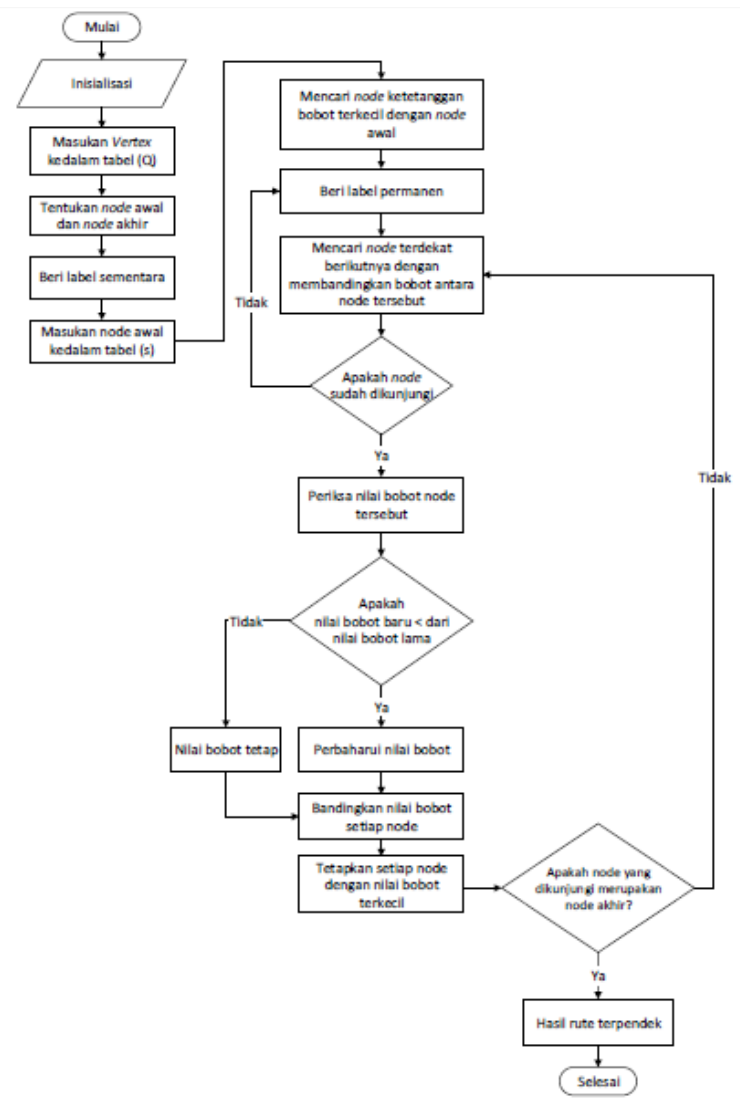

Gambar 1. Flowchart Proses Algoritma Dijkstra

Secara umum, algoritma pencarian jalur terpendek pada Website Pencarian Rumah Kos dan Kontrakan dapat dituliskan sebagai berikut:

a. Ambil node masukan dalam himpunan (Q)

b. Tentukan node awal dan node tujuan.

c. Beri label sementara nilai tak hingga pada setiap node dan node awal diberi label (0)

d. Periksa nilai bobot terkecil pada node ketetanggaan dengan node awal. 
e. Hapus label sementara dan beri label permanen pada node yang dikunjungi

f. Periksa node berikut yang dikunjungi apakah node sudah pernah dikunjungi. Bandingkan bobot nilai baru dengan bobot nilai lama

g. Melakukan proses dari langkah 6, sampai dapatkan akhir hasil proses jalur terpendek pada node akhir.

h. Menampilkan hasil jalur terpendek pada peta.

\subsection{Desain Software}

Desain system website ini, berkaitan dengan keseluruhan untuk menjabarkan hasil Analisa penelitian dalam pembuatan proses website dengan mengunakan Use Case Diagram seperti gambar 1. Pada use case diagram ini terdapat use case sisi pengguna dan use case pemilik.

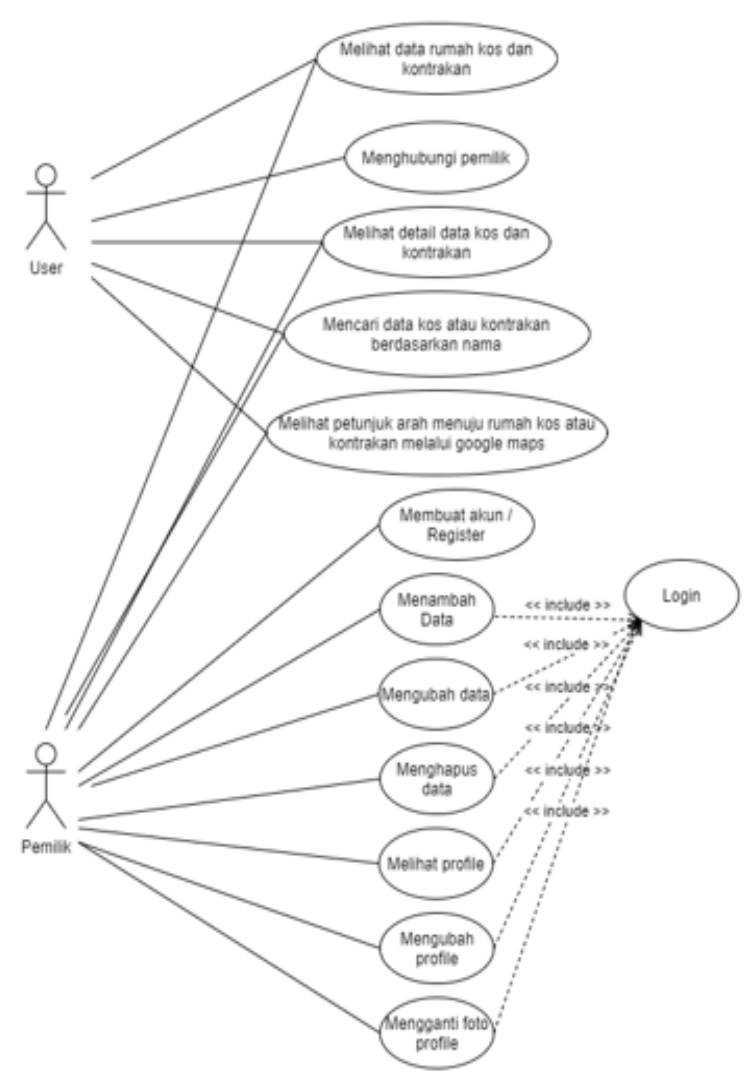

Gambar 1. Rancangan Use Case Diagram

Pada rancangan Class Diagram penulis membuat 2 Class Diagram.

a. Class Pemilik: class pemilik menggambarkan attribute dan methode apa saja yang dimiliki oleh pemilik didalam website ini.

b. Class Rumah: class rumah mendefinisikan rumah kos atau kontrakan yang dimiliki oleh pemilik. Class rumah menggambarkan attribute dan methode apa saja yang dimiliki oleh rumah. 


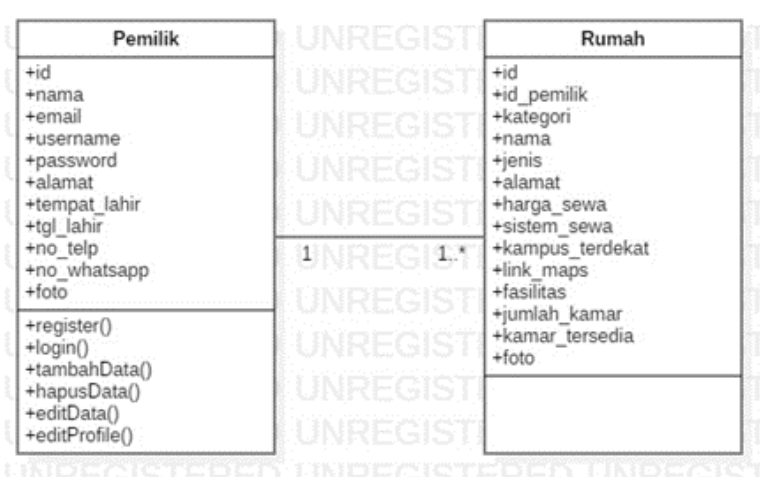

Struktur navigasi situs web digunakan untuk menggambarkan secara garis besar isi dari keseluruhan situs web. Pada struktur navigasi user terdapat bagianbagian sebagai berikut:

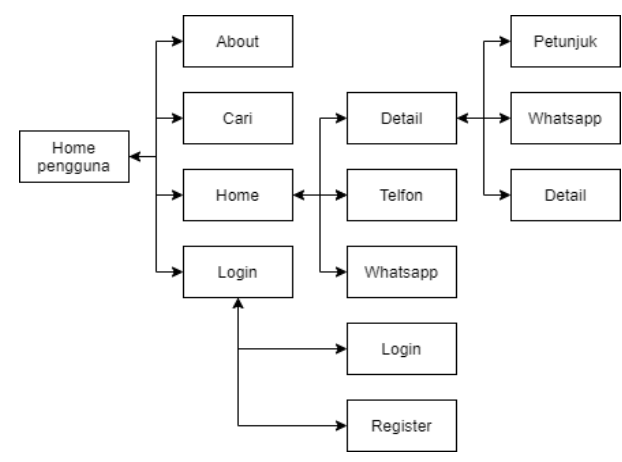

a. Home: Merupakan halaman pertama yang dilihat oleh pengguna

b. About: Merupakan halaman yang berisi informasi tentang website

c. Cari: Merupakan menu yang berguna untuk mencari rumah kos atau kontrakan berdasarkan nama.

d. Login: Merupakan halaman yang digunakan login sebagai pemilik rumah kos atau kontrakan.

e. Detail: Merupakan menu yang berfungsi untuk melihat detail informasi dari rumah kos atau kontrakan yang dipilih

f. Whatsapp: Merupakan menu yang berfungsi untuk menghubungi pemilik kos atau kontrakan yang dipilih melalui whatsapp

g. Telfon: Merupakan menu yang berfungsi pemilik kos atau kontrakan yang dipilih melalui telfon

h. Petunjuk: Merupakan menu yang berfungsi untuk melihat petunjuk jalan menuju rumah kos atau kontrakan yang dipilih melalui google maps

Pada struktur navigasi admin terdapat bagian-bagian sebagai berikut: 


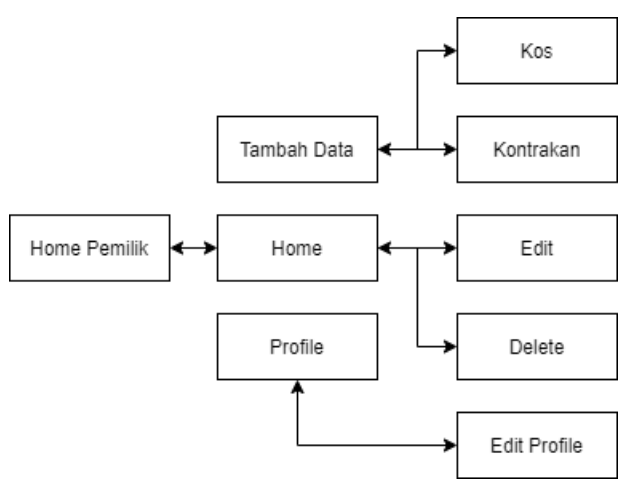

i. Home: merupakan halaman pertama saat kita melakukan proses login. Didalam Home terdapat tombol delete dan edit.

j. Delete: menu ini berfungsi untuk menghapus data rumah kos dan kontrakan.

k. Edit: menu ini berfungsi untuk mengubah data rumah kos atau kontrakan.

l. Tambah Data: merupakan menu untuk menambah data kos atau kontrakan baru. Didalam menu tambah data terdapat 2 opsi yaitu kos dan kontrakan untuk menentukan apakah data yang akan diinput merupakan data rumah kos atau kontrakan.

m. Buat kategori produk: halaman yang membuat kategori produk.

n. Profile: halaman profile menampilkan profile lengkap dari pemilik kos atau kontrakan yang telah login.

o. Edit Profile: menu ini berfungsi untuk mengubah data profil dari pemilik kos atau kontrakan.

\section{HASIL DAN PEMBAHASAN}

\subsection{Ujicoba Algoritma}

Untuk mengetahui dan menguji kemampuan dari kedua algoritma, dilakukan ujicoba pada kedua algoritma dengan menggunakan parameter pengujian yang telah ditentukan, yaitu waktu pemrosesan dan banyaknya sumber daya memori yang dipakai. Hasil dari kedua algoritma akan dibandingkan dan pada akhirnya ditentukan algoritma mana yang paling efektif dalam mencari rute terdekat. Hasil dari algoritma yang paling efektif juga akan dibandingkan dengan hasil rute dari aplikasi Google Maps menggunakan parameter yang sama.

Setelah program diinputkan titik (node) awal dan akhir yang telah ditentukan pada peta labirin yang tampilannya disesuaikan dengan tampilan peta google maps, didapatkan tampilan rute yang berbeda dari kedua Algoritma.

Perbedaan tersebut disebabkan oleh masing-masing algoritma menerapkan dua mekanisme yang berbeda. Penelitian diulang sebanyak 10 kali percobaan untuk mencari nilai rata-rata dari setiap algoritma sehingga data yang dihasilkan akan lebih valid. Dari percobaan ini, di dapatkan hasil: 


\begin{tabular}{cccccc}
\hline \multicolumn{3}{c}{ Algoritma Dijkstra } & \multicolumn{3}{c}{ Algoritma Astar } \\
\hline $\begin{array}{c}\text { Pengujian } \\
\text { ke- }\end{array}$ & $\begin{array}{c}\text { Waktu } \\
\text { Pemrosesan } \\
\text { (detik) }\end{array}$ & $\begin{array}{c}\text { Persentase } \\
\text { Utilisasi CPU } \\
(\%)\end{array}$ & $\begin{array}{c}\text { Pengujian } \\
\text { ke- }\end{array}$ & $\begin{array}{c}\text { Waktu } \\
\text { Pemrosesan } \\
\text { (detik) }\end{array}$ & $\begin{array}{c}\text { Persentase } \\
\text { Utilisasi } \\
\text { CPU (\%) }\end{array}$ \\
2 & 0,7 & 24 & 1 & 0,2 & 14 \\
3 & 0,2 & 17 & 2 & 0,3 & 12 \\
4 & 0,2 & 16 & 3 & 0,8 & 13 \\
5 & 0,1 & 18 & 4 & 0,3 & 16 \\
6 & 0,5 & 26 & 5 & 0,5 & 10 \\
7 & 0,2 & 9 & 6 & 0,2 & 3 \\
8 & 0,4 & 22 & 7 & 0,3 & 9 \\
9 & 0,2 & 14 & 8 & 0,1 & 11 \\
10 & 0,8 & 28 & 9 & 0,1 & 2 \\
Rata-Rata & 0,2 & 20 & 10 & 0,2 & 3 \\
\hline
\end{tabular}

Dari percobaan tersebut, ternyata rute dari Algoritma $A^{*}$ adalah rute yang paling mendekati metode pencarian yang dilakukan Google Maps itu sendiri. Dari percobaan ini, dengan objek dari node mulai dan node tujuan yang sama, disimpulkan bahwa Algoritma A* dapat menentukan waktu proses pencarian rute terdekat dengan lebih cepat dengan rata-rata waktu 0.3 detik.

Jika dibandingkan dengan penelitian-penelitian terdahulu, dari penelitian ini didapatkan kesamaan hasil pengujicobaan, yaitu dalam perbandingan antara algoritma Dijkstra dan Astar, Algoritma astar memiliki tingkat keoptimalan yang lebih besar dari Dijkstra. Tetapi pada parameter-parameter tertentu, algoritma Dijkstra dapat mencari rute lebih cepat disbanding Astar. Oleh karena itu aplikasi ini menggunakan kedua algoritma untuk mencari rute dan jarak pada peta lalu menentukan hasil terbaik dari kedua algoritma.

\subsection{Implementasi Pembuatan Website}

Pada pembuatan website, dilakukan konfigurasi database terlebih dahulu pada file .env, untuk menghubungkan antara php dengan database mysql yang telah dibuat.

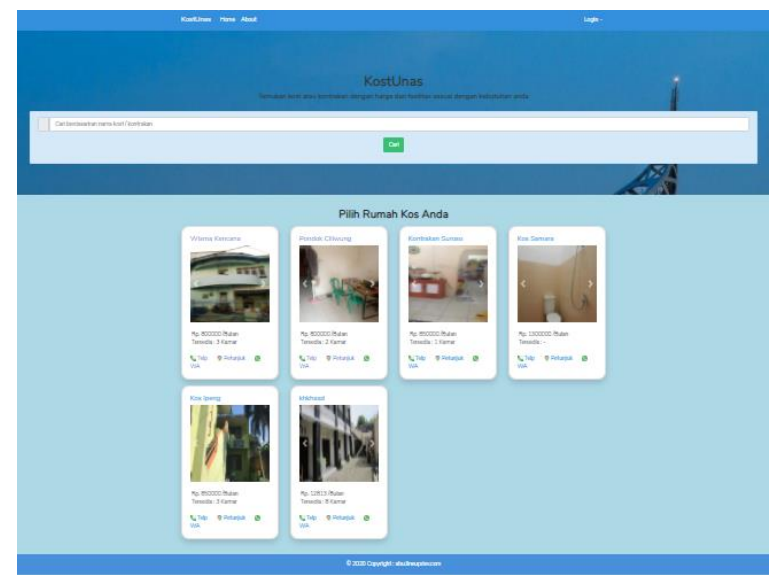

Gambar 6. Tampilan Halaman Depan 


\subsubsection{Tampilan Halaman Login}

Halaman login merupakan halaman yang dibuat untuk pemilik yang membuat akun terlebih dahulu, jika belum membuat maka harus registrasi terlebih dahulu di halaman yang sama pada saat login. Tampilan halaman login dan register dapat dilihat pada gambar 7 dan gambar 8 .

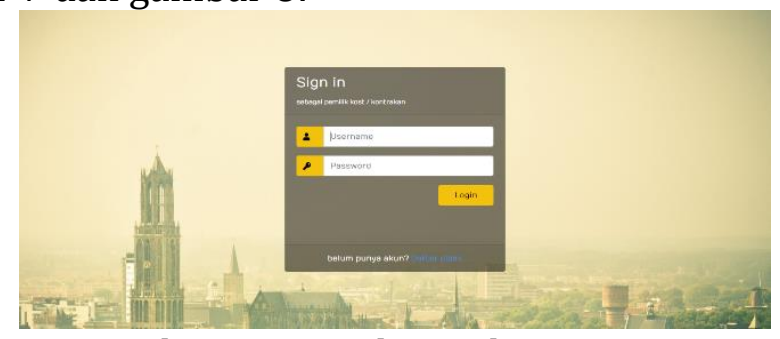

Gambar 7 Tampilan Halaman Login

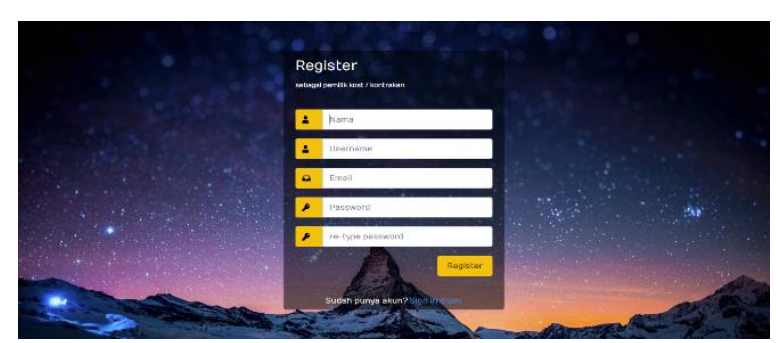

Gambar 8 Tampilan Halaman Register

\subsubsection{Tampilan Halaman Detail}

Halaman ini berfungsi untuk melihat detail dari data rumah kos dan kontrakan yang dipilih. Tampilan halaman detail dapat dilihat pada Gambar 9.

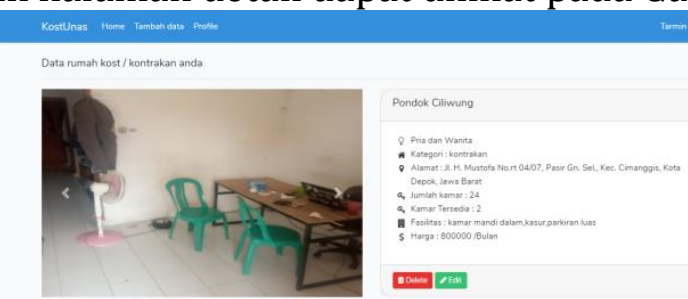

Gambar 9. Tampilan Halaman Detail

\subsubsection{Tampilan Halaman Tambah Data}

Halaman tambah data berfungsi untuk menambahkan data rumah kos atau kontrakan setelah pemilik login kedalam website. Tampilan halaman tambah data dapat dilihat pada Gambar 10. 


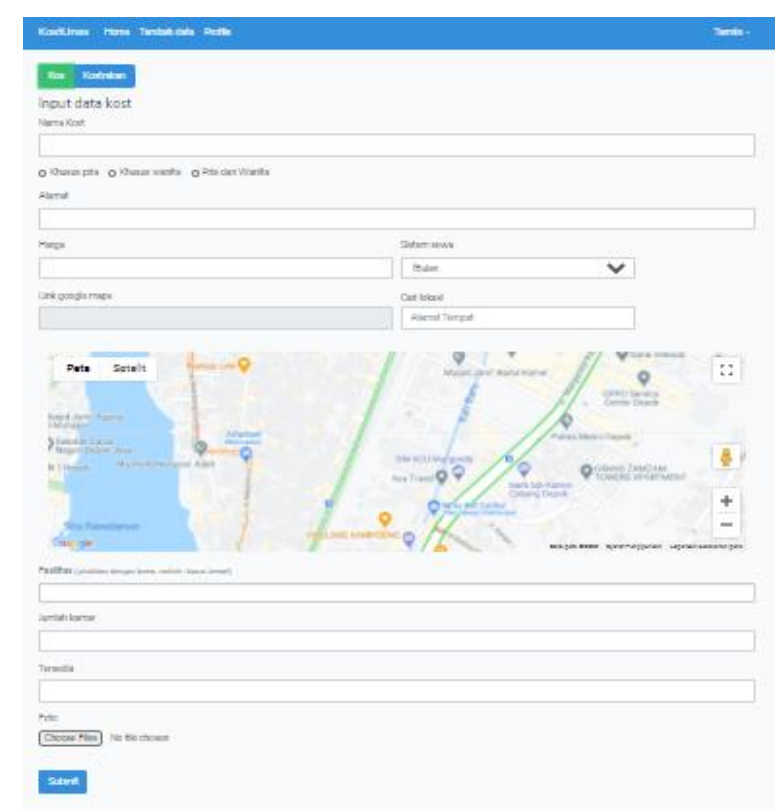

Gambar 10. Tampilan Halaman Tambah Data

\subsubsection{Tampilan Halaman Profile}

Halaman profile berisi data profil pemilik yang sudah login. Tampilan halaman profile dapat dilihat pada Gambar 11.

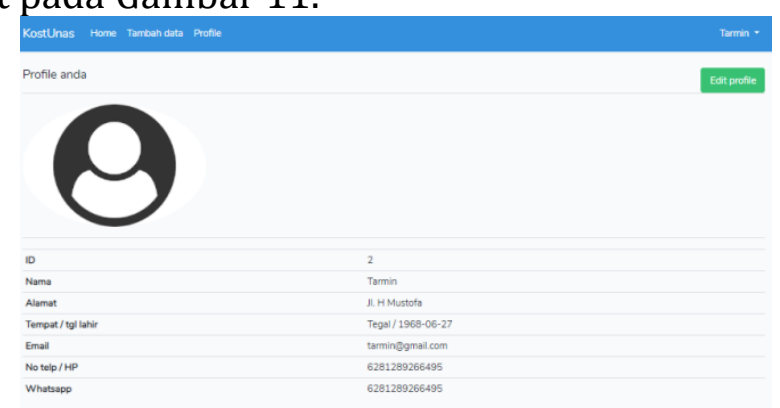

Gambar 11 Tampilan Halaman Profile

\section{SIMPULAN}

Website pencarian rumah kos dan kontrakan disekitar kampus Universitas Nasional berhasil dibuat dan dapat mempermudah para mahasiswa baru dari luar daerah untuk mencari tempat tinggal di sekitar kampus. Uji coba fitur dan tampilan website ini dilakukan menggunakan laptop dan smartphone dan mendapatkan hasil yang sesuai.

Pada pengujicobaan algoritma juga didapatkan kesimpulan, yaitu Algoritma A* bekerja lebih baik dan lebih efisien daripada Algoritma Dijkstra. Selain itu, data membuktikan bahwa waktu yang dibutuhkan Algoritma $A^{*}$ lebih stabil dari pada Algoritma Dijkstra. 


\section{DAFTAR PUSTAKA}

[1] S. S. Sundari and I. Komarudin, "PERANCANGAN SISTEM INFORMASI RUMAH KOST BERBASIS WEB DAN SHORT MESSAGE SERVICE (SMS) MENGGUNAKAN PHP DAN MySQL," Seminar Nasional Informatika, 2015.

[2] A. Gusmão, S. H. Pramono and S. , "Sistem Informasi Geografis Pariwisata Berbasis Web Dan Pencarian Jalur Terpendek Dengan Algoritma Dijkstra," Jurnal EECCIS, vol. 7, 2013.

[3] A. C. Prasetyo, M. P. Arnandi, H. S. Hudnanto and B. Setiaji, "Perbandingan Algoritma Astar dan Dijkistra Dalam Menentukan Rute Terdekat," Jurnal Ilmiah SISFOTENIKAJuly201xIJCCS, vol. 9, 2019.

[4] S. Arfida, A. and H. Wibowo, "APPLICATION OF THE DIJKSTRA ALGORITHM IN THE DISSEMINATION OF LOCATION OF CERTIFIED TEACHING STAF OF LAMPUNG PROVINCE PUBLIC," ICITB.

[5] D. Hermanto and S. Dermawan, "Penerapan Algoritma A-Star Sebagai Pencari Rute Terpendek pada Robot Hexapod," Jurnal Nasional Teknik Elektro, vol. 7, 2018.

[6] H. D. Yunita, "SISTEM INFORMASI RUMAH KOST DI BANDAR LAMPUNG," 2018.

[7] N. Gupta, K. Mangla, A. K. Jha and M. Umar, "International Journal of New Technology and Research (IJNTR)," Applying Dijkstra's Algorithm in Routing Process, vol. 2, no. 5, p. 124, 2016.

[8] A. Sofyan, "Sistem Aplikasi Penentuan Rute Terpendek Pada Jaringan Multi Moda Transportasi Umum Menggunakan Algoritma Dijkstra," Tesis Universitas Diponegoro, 2012.

[9] S. Jung, B. Goo and H. Jin, "Development of a Sequential Restoration Strategy Based on the Enhanced Dijkstra Algorithm for Korean Power Systems," MDPI, 2016.

[10] B. Amaliah, C. Fatichah and O. Riptianingdyah, "FINDING THE SHORTEST PATHS AMONG CITIES IN JAVA ISLAND USING NODE COMBINATION BASED ON DIJKSTRA ALGORITHM," INTERNATIONAL JOURNAL ON SMART SENSING AND INTELLIGENT SYSTEMS, vol. 9, 2016.

[11] I. Makohon, D. T. Nguyen, M. Sosonkina, Y. Shen and M. Ng, "JAVA BASED VISUALIZATION AND ANIMATION FOR TEACHING THE DIJKSTRA SHORTEST PATH ALGORITHM IN TRANSPORTATION NETWORKS," International Journal of Software Engineering \& Applications, vol. 7, 2016. 
[12] F. E. Andiany and W. Hadikurniawati, "IMPLEMENTASI ALGORITMA DIJKSTRA UNTUK MENCARI RUTE TERPENDEK ANTAR KANTOR DAN ESTIMASI PENGGUNAAN BAHAN BAKAR KENDARAAN (STUDI KASUS PT. TELKOM INDONESIA REGIONAL IV JATENG-DIY)," ISBN, 2018.

[13] A. Triayudi, E. Prameswari and I. Sholihati, "Web-based E-diagnostic for Digestive System Disorders in Humans using the Demster Shafer Method," Intrenational Journal od COmputer Applications, 2019.

[14] A. Triayudi and A. Rhodi, "Waterfall Modelling Pada Sistem E-Restorant," ProTekInfo (Pengembangan Riset dan Observasi Teknik Informatika), vol. 5, 2018.

[15] M. Irawan, A. Triayudi and I. Sholihati, "Perancangan User Interface Design dan User Experience Mobile Responsive Pada Website Perusahaan," JURNAL MEDIA INFORMATIKA BUDIDARMA, vol. 4, 2020. 